\title{
PENDAMPINGAN GURU SMPLB DALAM MEMANFAATKAN KULIT JAGUNG SEBAGAI MEDIA KREASIKHAS KOTA GARUT
}

\author{
Mudjiati \\ Jurusan Seni Rupa Fakultas Bahasa Dan Seni Universitas Negeri Jakarta
}

\begin{abstract}
ABSTRAK
Garut merupakan merupakan salah satu wilayah yang memiliki Sumber Daya Alam yang melimpah selain dari komoditas padi dan tembakaunya, Garut juga penghasil komoditas jagung yang sangat potensial.Sehingga banyak juga menghasilkan kulit jagung yang sangat memungkinkan untuk dijadikan cinderamata seperti bunga, aksesoris, dan penghias beragam peralatan rumah tangga seperti tempat tisu, toples, keranjang, dan sebagainya.Dengan begitu, tercipta karya seni yang ramah lingkungan, green craft atau eco craft, yang sangat potensial dalam menunjang pariwisata Garut apabila dikembangkan dengan baik. Seiring dengan perkembangan industri kreatif, Universitas Negeri Jakarta saat ini memberikan kontribusinya dalam kegiatan P2M di Kota Garut oleh siswa/i dan guru-guru SMPLB B dan C untuk memberikan media pembelajaran kreatif dalam pemanfaatan limbah kulit jagung menjadi produk seni yang bernilai jual tinggi. Pemanfaatan kuli jagung tersebut dikenal dengan Kelobot Art dengan teknik merangkai, koase, dan menganyam.

Dengan demikian, harapan pengabdian kepada masyarakat ini dapat ikut berpartisipasi memberdayakan peningkatan Sumber Daya Manusiadibidang pendidikanmelalui sosialisasi pengetahuan dan keterampilan pembuatan kreasi kulit jagung khas Garut (Kelobot Art) dengan teknik merangkai, kolase, dan menganyam.Metode yang digunakan adalah metode presentasi, tanya jawab, metode demonstrasi dan praktek.
\end{abstract}

Kata Kunci : Desa, Klobot Art, teknik merangkai, kolase, dan menganyam

\section{PENDAHULUAN}

Garut merupakan salah satu penghasil komoditas kulit jagung yang besar di wilayah Jawa Barat. Sebagai daerah yang kaya akan kekayaan alamnya, salah satunya jagung. Tanaman jagung biasa hanya digunakan jagungnya saja, namun kulit jagung juga bisa dimanfaatkan sebagai media kreasi yang menghasilkan karya unik serta memiliki nilai yang tinggi.Kreasi dari kulit jagung merupakan pembelajaran kriya dalam mata pembelajaran seni rupa.

Salah satu kerajinan khas dari Garut adalah kriya kulit jagung yang di buat berbagai jenis bunga.Namun kerajinan tersebut hanya diketahui beberapa masyarakat saja, tanpa eksplorasi lebih yang dapat menjadi lahan industri kreatif sehingga kerajinan tersebut kini tidak dikembangkan di daerahnya. Melalui kegiatan
P2M yang dilakukan oleh Universitas Negeri Jakarta ini akan mengembangkan pengetahuan dan keterampilan melalui pendampingan guruguru dan siswa/i SMPLB B dan C Kota Garut dalam membuat Kelobot Art menjadi berbagai jenis produk berdaya guna dan bernilai seni.

Media pembelajaran Kelobot Art ini, selain memberikan siswa/i juga guru-guru SMPLB B dan C Kota Garut keterampilan dalam membuat produk seni kriya berbahan dasar kelobot jagung, juga dapat memberikan pembelajaran seni berkarakter kepada siswa/i dengan memiliki rasa kepedulian terhadap lingkungan melalui pemanfaatan limbah kelobot jagung menjadi produk atau benda yang memiliki nilai guna. Dengan pemanfaatan limbah kelobot jagung tersebut, tanpa disadari siswa/i telah berperan aktif meminimalisir limbah kelobot jagung yang merupakan salah satu 
limbah yang menyebabkan pencemaran lingkungan.

Disinilah sikap kepedulian yang mulai sejak dini ditanamkan pada masing-masing peserta didik. Bukan hanya itu, dengan adanya pembelajaran seni kriya Kelobot Art akan menanamkan jiwaentrepreneur,yang tangguhdan mandiri, sehingga adanya pembelajaran Kelobot Art ini akan menjadi suatu ilmu kewirausahaan yang dapat diaplikasikan/implementasikan ke depannya. Kelobot jagung dapat dengan mudah diperoleh dikarenakan kulit jagung (kelobot) merupakan varietas tumbuhan yang tidak termasuk varietas tanaman semusim yanghasil panennya hanya dapat dipanen satu musim atau satu tahun musim panen saja.

\section{METODE}

Khalayak sasaran antara yang strategis dalam pengabdian masyarakat ini adalah guruguru SMPLB Garut yang terdiri dari 12 SMPLB $\mathrm{B}$ dan $\mathrm{C}$ atau tuna grahita dan tuna rungu, diutamakan siswa-siswi kelas VIII dan kelas IX SMP dengan beberapa guru yang mendampinginya dan memiliki minat dalam bidang pembuatan karya seni kriya (kreasi bunga) dengan kulit jagung.

Pendampingan keterampilan terhadap guruguru SMPLB Garut yang terdiri dari 12 SMPLB $\mathrm{B}$ dan $\mathrm{C}$ atau tuna grahita dan tuna rungu ini dilakukan dalam dua tahap, meliputi: (1) Mempresentasikan objek-objek nyata dalam bentuk video, power point, dan karya seni hasil dari limbah kulit jagung. (2) Menjelaskan sistematika pembuatan karya seni kriya dari kulit jagung. Kemampuan penalaran dalam studi penciptaan karya seni rupa meliputi: (1) adanya objek yang diciptakan, (2) adanya subjek pembuat karya seni, (3) Pertemuan antara subjek dan objek seni. Oleh karena itu, ketiganya harus selalu ada dalam proses penciptaan karya seni dan penelitian ilmiah. Apabila antara keduanya yakni subjek dan objek seni tidak ada, maka aktivitas penelitian ilmiah atau aktivitas penciptaan karya seni (seni kriya dari limbah kulit jagung) tidak ada.

\section{Metode yang digunakan adalah:}

1) Metode presentasi, digunakan untuk menyampaikan materi yang berupa teori pembuatan kreasi bunga dari kulit jagung dalam bentuk ppt dan video tutorial.

2) Metode tanya jawab, digunakan untuk memberikan kesempatan bagi peserla yang belum jelas dalam pemahamannya.

3) Metode demonstrasi; digunakan untuk memperagakan teknik membuat berbagai bentuk dan jenis bunga.

4) Metode Latihan/Praktek, digunakan untuk latihan/praktek membuat kreasi bunga dari kulit jagung (Klobot Art) berupa berbagai jenis bunga mawar, bunga aster, bunga sedap malam, kembang sepatu, membuat hiasan buku harian, dan sebagainya

5) Metode diskusi, digunakan pada waktu setelah dilakukan evaluasi hasil praktek peserta pelatihan.

\section{Ada dua tahap evaluasi yang akan dilakukan} dalam pelatihan pengabdian ini, yaitu:

1. Evaluasi pada akhir pelatihan, yang dimaksudkan untuk mengetahui tingkat pemahaman dan keterampilan peserta, dengan menilai hasil praktek adapun kriteria yang digunakan adalah sebagai berikut:

$$
\begin{array}{ll}
\mathrm{A}=85 \%-100 \% & =\text { sangat baik } \\
\mathrm{B}=70 \%-84 \% & =\text { baik } \\
\mathrm{C}=60 \%-69 \% & =\text { cukup } \\
\mathrm{D}=0 \%-59 \% & =\text { kurang }
\end{array}
$$

2. Evaluasi pada akhir pelatihan, untuk mengetahui keberhasilan pelaksanaan pengabdian pada masyarakat yang dilakukan oleh tim pengabdian. Pelaksanaan Pengabdian Kepada Masyarakat berupa pelatihan keterampilan, melalui 3 tahap yaitu persiapan, pelaksanaan, dan evaluasi. Adapun rincian kegiatan yang dilaksanakan yaitu:

1. Tahap Persiapan;
a. Perizinan
b. Persiapan materi ,bahan, alat, petunjuk praktek. 


\section{Tahap Pelaksanaan}

a. Pertemuan I : Pembukaan dan penyampaian materi teori dan praktek.

b. Pertemuan II : Praktek membuat klobot art untuk membuat berbagai jenis bunga,danhiasan pada buku harian, membuat bingkai foto dari kuli jagung, tempat pensil, dan sebagainya.

c. Pertemuan III : Penyelesaian dilanjutkan evaluasi hasil dan penutupan.

Dalam rangka memecahkan masalah yang sudah diidentifikasi pada uraian di atas maka metode kegiatan pengabdian kepada masyarakat dilakukan oleh tim pengabdian adalah berbentuk penyampaian informasi dan pelatihan.

Adapun materinya terdiri dari teori dan praklek. Materi tersebut secara garis besar dirinci sebagai berikut :

\section{Bahan dan Alat}

a. Kulit Jagung

b. Pewarna Tekstil: Warna hijau, kuning, orange, merah muda, merah, dan lainlain.

c. Pewarna Alam: kulit secang (memberi warna merah), kunyit (memberi warna kuning), dan daun mangga (memberi warna hijau).

d. Gunting dan satu gulung batang kawat lunak (1 meter) dipotong menjadi $10 \mathrm{~cm}$ atau batang lidi.

e. Klorotif

f. Lem Tembak dan lem kayu

g. Kompor Listrik

h. Polyfoam dan benang

2. Tahap pengerjaan bunga mawardengan kulit jagung

a. Membuat desain pola makhota bunga mawar.

b. Mencetak pola mahkota bunga mawar.

c. Menggunting kelobot jagung dengan mengikuti pola bentuk makhota yang dibuat.

d. Merapikan bagian sisi paling bawah dari kulit jagung. e. Melipat menjadi dua bentuk pola yang sudah dibentuk sebelumnya.

f. Melipat dengan arah vertikal kemudian gunting untuk mendapat bentuk yang sama.

g. Gulung dari bagian ujung kelobot yang telah digunting,hingga mendapatkan pola bentuk radial/spiral

h. Ambil satu batang kawat. Untuk menempelkan bentuk radial kelopak, pada batang kawat.

i. Kemudian tempelkan dengan menggunakan lem tembak.

j. Menempelkan pola mahkota bungasatu persatu mulai dari kelipatan ganjil yang paling kecil (3,5, dan7).

k. Lapisi bagian kawat/lidi dengan klorotif.

l. Tempelkan pola daun yang sudah jadi pada bagian batang kawat/lidi, kemudian lapisi kembali dengan klorotif.

Kegiatan ini merupakan program P2M Universitas Negeri Jakarta yang dalam pelaksanaannya membutuhkan keterkaitan Lembaga Pengabdian Kepada Masyarakat dan ini memiliki keterkaitan dengan peningkatan sumber daya manusia khususnya pada guru-guru SMPLB Garut yang terdiri dari 12 SMPLB B dan $\mathrm{C}$ atau tuna grahita dan tuna rungu serta pemberdayaan keterampilan untuk mencapai SDM (Sumber Daya Manusia) yang kreatif, inovatif dalam bidang pendidikan yang bertolak ukur pada pendidikan seni khususnya seni rupa dalam rangka ikut meningkatkan diri dan untuk berwirausaha di bidang pembuatan Kelobot Art menjadi produk bernilai jual tinggi.

\section{PEMBAHASAN DAN HASIL}

\section{A. Pembahasan}

1. Mengkaji hasil yang dicapai oleh para peserta yaitu $75 \%$ berhasil dengan kriteria baik, maksudnya pemahaman peserta tentang pengertian tujuan dan teknik sudah baik, dan dari aspek teknik penyelesaian, keindahan dan kecepatan juga baik. Sedangkan hasil 25\% dari peserta yang memperoleh kriteria cukup, siswa-siswi SMPLB B dan C pada umumnya aspek 
kecepatan dan kerapihan belum dapat melakukannya dengan baik, artinya 25\% dari peserta tersebut kerjanya harus membutuhkan bimbingan yang lebih khusus dan belum dapat membuat Klobot Art dengan rapi dan proporsi.

2. Pelaksanaan kegiatan ini, tim pengabdian tidak banyak mengalami hambatan yang, berarti. Hal ini disebabkan penyelenggaraan ini dilakukan pada pertemuan rutin antara tim pengabdi dengan pihak komponen sekolah SMPLB B dan C kOTA Garut. Selain itu, peserta merasa membutuhkan pengetahuan dan keterampilan membuat kreasi Klobot Art dengan teknik merangkai, kolase, dan anyam, untuk menciptakan ruang kelas, mading sekolah, maupun ruang kantor agar lebih indah dengan adanya karya seni dari kulit jagung. Hal ini ditunjukkan jumlah peserta yang konsisten sesuai dengan kesepakatan yaitu 24 orang untuk dua sekolah.Respon semua pihak sekolah seperti Kepala Sekolah, Wakil Kepala Sekolah, maupun para guru SMPLB $\mathrm{B}$ dan $\mathrm{C}$ juga sangat menunjang baik penyiapan fasilitas tempat, Tetapi ada sedikit kendala yang menghambat jalannya pelaksanaan ini, antara lain waktu yang terbatas, sehingga siswa/i maupun guru tidak bisa menyelesaikan hasil karya mereka dalam waktu sehari dan dilanjutkan dihari berikutnya.

3. Faktor pendorong yang mempengaruhi kelancaran pclaksanaan kegiatan ini adalah keinginan peserta untuk memperoleh pengetahuan dan keterampilan. Selain itu, Kepala Sekolah maupun Wakil Kepala Sekolah SMPLB B dan C Kota Garut juga ikut sebagai peserta pelatihan sehingga memacu peserta yang lain untuk lebih semangat dan aktif.

4. Relevansi kegiatan ini dapat memperkenalkan dan menambah pengetahuan dan keterampilan peserta didik maupun para pendidik SMPLB B dan C di Kota Garut untuk lebih kreatif dan inovatif membuat media pembelajaran yang menyenangkan juga bermakna. Bagi tim pengabdian masyarakat merupakan penerapan langsung dari materi-materi mata kuliah yang dipelajarinya, sehingga dapat rnendharmabaktikan kemampuan sesuai dengan perkembangan zaman.

5. Tindak lanjut kegiatan ini diharapkan para siswa/i maupun guru-guru SMPLB B dan C Kota Garut memperoleh dasar pengetahuan dan keterampilan membuat kreasi dengan teknik merangkai, kolase dan anyam, dapat sering berlatih dan rnenekuninya yang memungkinkan dapat sebagai bekal untuk usaha di bidang jasa membuat kreasi Klobot Art dengan teknik merangkai, kolase, dan anyam. Selain itu dapat menyampaikan dan disebarluaskan kepada siswa/i maupun guru-guru yang belum mendapat kesempatan mengikuti pelatihan membuat kreasi bunga dari kulit jagung (Klobot Art) khas Garut dengan teknik merangkai, kolase, dan menganyam.

\section{B. Hasil}

Hasil pengabdian kepada masyarakat dijabarkan dalam 3 aspek, yakni: kehadiran peserta, partisipasi dan kesungguhan peserta serta hasil praktek/latihan.

1. Kehadiran peserta

Sasaran yang dilibatkan dalam kegiatan ini adalah guru-guru SMPLB Garut yang terdiri dari 12 SMPLB B dan C atau tuna grahita dan tuna rungu.Pada pelaksanaan kegiatan jumlah peserta yang hadir sesuai dengan kesepakatan yaitu 24peserta.Selama 3 hari pertemuan kehadiran 100\% atau tidak ada yang absen.

2. Partisipasi dan kesungguhan peserta

Paritisipasi dan kesungguhan peserta dapat dikatakan baik. Hal ini terlihat dari kesungguhan peserta dalam mengikuti kegiatan, demonstrasi maupun melakukan praktek. Hal ini didukung dengan kesempatan yang diberikan kepada peserta untuk praktek dan membawa pulang hasil tersebut kemudian mengadakan pameran yang dilakukan pihak sekolah di Mall Ramayana Kota Garut. 


\section{Tahap Pelaksanaan}

3

- Hasil pelatihan keterampilan membuat kreasi bunga, bingkai foto, dan sebagainya dengan teknik rangkai, kolase, dan anyam.

Berdasarkan hasil pengamatan selama pelaksanaan dan pemantauan \{TOT (Monitoring) \}yang telah dilaksanakan diperoleh hasil :

a. Peserta pelatihan sangat antusias saat diberikan materi teori baik berupa video atau ppt, bahan, alat-alat yang digunakan untuk

membuat Klobot Art dengan teknik rangkai,kolase, dan anyam. Halini terlihat dari, diskusi antara tim pengabdi dengan peserta. dan hasil karya Klobot Art yang dibuat para guru maupun siswa/i SMPLB Garut.

b. Praktek yang dilakukan adalah membuat kreasi bunga dari kulit jagung berupa bunga mawar, bunga aster, bingkai photo, hiasan buku harian dengan teknik merangkai, kolase, dan menganyam. Para siswa/i yang didampingi oleh masing-masing guru, yang mana sesuai dengan waktu yang telah disepakati peserta, dapat menyelesaikan membuat Klobot Artdengan teknik merangkai, kolase, dan menganyam dimana penerapannya pada kreasi bunga, mading sekolah, vas bunga, bingkai foto, dan hiasan buku harian .

\section{KESIMPULAN DAN}

\section{SARAN A. Kesimpulan}

Hasil pelaksanaan pengabdian kepada masyarakat menunjukkan bahwa siswa/i dan e. Melipat menjadi dua bentuk pola yang

guru-guru SMPLB B dan C Kota Garut peserta

pelatihan tentang pengetahuan dan keterampilan membuat kreasi kulit jagung (Klobot Art) dengan teknik merangkai, kolase, dan menganyam melalui metode presentasi, tanya jawab, demonstrasi oleh tim pengabdian, maka para peserta dapat mengenal dan memahami materi pelatihan. Selain itu, baik siswa/i maupun para guru SMPLB B dan C Kota Garut melalui metode latihan / praktek dapat membuat / mempraktekkan membuat berbagai kreasi Klobot Art berupa kreasi jenis bunga, vas, bross, hiasan buku harian, bingkai foto, dan sebagainya dengan teknik merangkai, kolase, dan meng- anyam dengan hasil $75 \%$ peserta berhasil dengan kriteria baik dan 25\% peserta berhasil dengan kriteria cukup.

B.

\section{Saran}

Saran yang dapat diajukan berdasarkan hasil kegiatan adalah kepada guru-guru SMPLB B dan C Kota Garut sebagai Tim Pendidik anakanak berkebutuhan (tuna grahita atau tuna rungu) diwilayah Garut agar menyampaikan dan menyebarluaskan pengetahuan dan keterampilan yang telah diperoleh kepada masyarakat sekitarnya dengan pelatihan membuat Klobot Art (kreasi kulit jagung) berupa pengembangan produk yang berbeda dari yang dibibimbing oleh Tim Pengabdi seperti membuat dompet, tas, dan lain sebagainya dengan teknik yang sama yaitu merangkai, kolase, dan menganyam. Kemudian, hendaknya pelatihan tersebut dapatlah sebagai dasar pengetahuan dan keterampilan, yang selanjutnya dapat ditekuni dan dikembangkan menjadi salah satu altenatif untuk membuka usaha dengan berwirausaha. 